\title{
Foreign Technologies and Indigenous Innovation Performance: Evidence from Selected African Countries
}

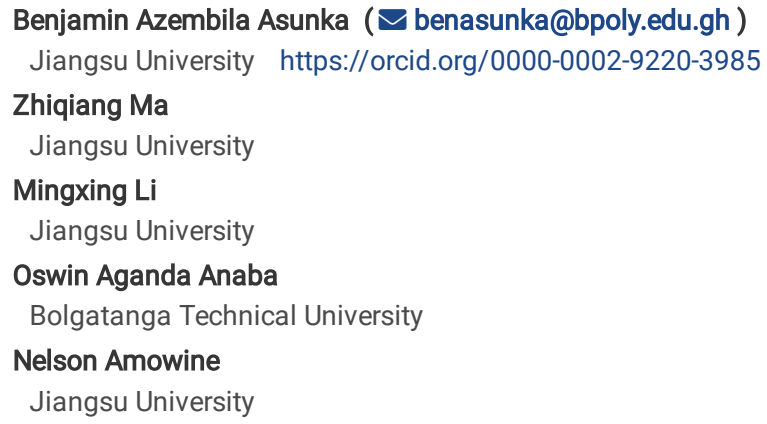

Research

Keywords: indigenous innovation, R\&D, trade openness, trademark, VECM, Africa

Posted Date: September 29th, 2020

DOI: https://doi.org/10.21203/rs.3.rs-84181/v1

License: (c) (7) This work is licensed under a Creative Commons Attribution 4.0 International License. Read Full License 


\section{Abstract}

This study analyzes the impact of imports and foreign direct investment inflows (FDI) on indigenous innovation in some selected African countries. Panel data of five African countries for the period between 1994 and 2018 is analyzed using trademark applications by residents as proxy for indigenous innovation. A vector error correction model is employed to analyze the short-run causality between variables, and fully modified ordinary least squares to analyze the longrun dynamics among variables. The results show that, on the whole, imported inputs have significant and positive effect on indigenous innovation output, while FDI has negative effects. Policy formulation in the region should encourage imports aimed at creating novel products.

\section{Introduction}

The growth of most African economies has been rather slow as compared to countries in other regions. Endogenous economic growth is largely influenced by how a country leverages indigenous knowledge to enhance economic activity that propels growth. Schumpeter (1934) argued that firm growth and industrial competition which influence economic growth are largely influenced by product innovation. Product innovation involves the development of new or improved product designs that can effectively meet the changing needs and tastes of the target consumers (Valencia, Valle, \& Jiménez, 2010). The African Union (AU) recently developed a Science, Technology and Innovation Strategy for Africa (STISA 2024) with a mission "to accelerate the transition of Africa to a knowledge-led, knowledge-based economy" (AU, 2013). STISA 2024 is aimed at promoting indigenous innovation in the region to support the agenda of economic growth. The concept of indigenous innovation was first hatched in China as an agenda to promote innovation among domestic firms. This concept emphasizes the creation of novel products (Liu, Schwaag Serger, Tagscherer, \& Chang, 2017), and has received a lot of attention from scholars since its inception (e.g. Vinig \& Bossink, 2015).

Indigenous innovation is one way of promoting endogenous growth in an economy through the combination of local expertise and resources to design and produce new products for both local and international consumption. This phenomenon promotes technological innovation, an important contributor to industrialization (Rodrigues \& da Costa, 2018; Intarakumnerd \& Goto, 2018). Industrialization that is mainly driven by indigenous innovation is a major determinant of sustainable economic growth in developing countries. Indigenous innovation in emerging markets suffers a setback due to a competitive business environment that is shaped by technological evolution that speeds up product life cycles making it difficult for businesses in such countries to keep up with the pace (Costa, Fernández, \& Dorrego, 2014). Meanwhile, business organizations in developing countries are faced with poor infrastructure (Debrah, Oseghale, \& Adams, 2018; Egbetokun, Atta-Ankomah, Jegede, \& Lorenz, 2016), and financial and market constraints (Corchuelo \& Carvalho, 2020). Innovation in Africa has generally experienced slow growth owing to several factors including human capital, economic infrastructure, and the changing nature of the business environment.

This study aims to unravel the potential of imports and foreign direct investment inflows (FDI) in promoting indigenous innovation in Africa. Most countries in Africa have opened up their markets to international trade, importing and exporting products across several sectors. Recently, Africa has taken a bold step to establish a free-trade area which according to the World Trade Organization, is the largest in the world. The African Continental Free Trade Area (ACFTA) involves almost every country on the continent. The major economic activities associated with trade openness include imports, exports, and foreign direct investments (FDI). Foreign technologies have been noted as a significant contributor to the growth of innovation in developing economies. imported inputs create 'escape-competition' which enhances creativity among local firms (Xie and Li, 2018; Seenaiah and Rath, 2018; Shu and Steinwender, 2019). Imported technologies create competition with domestic products which encourages local businesses to upgrade their product offerings to meet the changing needs of consumers (Medina 2017; Bloom, Draca, \& Van Reenen, 2016). Additionally, other scholars have argued that imported inputs serve as key drivers of productivity among domestic firms (Gopinath and Neiman, 2014; Foster-McGregor, Isaksson and Kaulich, 2014; Okafor, Bhattacharya and Bloch, 2017). However, others have found mixed effects of imported technologies on innovation output, while intermediate goods that have been imported have been found to have positive effects on innovation (Xie and Li, 2018; Shu and Steinwender, 2019).

Studies on innovation in the African context are rapidly growing. Various scholars have tried to unravel the factors that promote innovation activities on the continent. Factors that have been explored in these works include the role of technology absorption (Botchie, Sarpong, \& Bi, 2017), institutional factors (Egbetokun, Atta-Ankomah, Jegede, \& Lorenz, 2016), public policy (lizuka, Mawoko, \& Gault, 2015), and sources of innovation knowledge (Carlisle, Kunc, Jones, \& Tiffin, 2013). Most scholars in this study context have largely documented the challenges faced by firms in Africa in their quest to design new and improved products and services. Infrastructure to support innovation in the continent has been the main bane identified by several studies (Poole \& Penrose Buckley, 2006; Yepes, Pierce, \& Foster, 2009). Yepes et al., (2009) note that Africa's infrastructure lags behind other developing economies in other regions with similar per capita income. Future projections of Africa's infrastructure development indicates that the current trend will remain relatively low compared to similar developing economies (Woetzel, Garemo, Mischke, Hjerpe, \& Palter, 2016). Moreover, some studies have pointed out the role of institutions in the innovation process in the region, concluding that weak institutions limit interactive learning, thereby hindering innovation (Egbetokun, Siyanbola, \& Adeniyi, 2007; lizuka et al., 2015; Muok \& Kingiri, 2015). Added to these is the issue of human capital (HC) that is recognized as a major backbone of innovation in economies around the world. Unfortunately, in the context of Africa, $\mathrm{HC}$ is another factor that needs further investments to improve its contribution to indigenous innovation in the continent (Das \& Drine, 2020).

Interestingly, amid these challenges, the African Innovation Outlook III (2019) reports a good number of firms in the continent are engaged in innovation. Evidence from the report shows that firms in countries such as Kenya, Namibia, Uganda among others are performing very well terms of product innovation. This is an indication that indigenous innovation is still possible in the midst of poor infrastructure and underdeveloped systems. Gupta (2013) argues that indigenous innovations emerge when existing facilities and systems fail to adequately meet the needs of the populace.

The import of products from other countries and foreign direct investment inflows (FDI) have been directly linked to improvements in indigenous innovation in other regions (Xie \& Li, 2018; Seenaiah \& Rath, 2018; Shu \& Steinwender, 2019). In contributing to literature on this issue, this study brings to the fore the 
contribution of imported inputs and FDI to the innovation efforts of indigenous firms in the African continent.

The study is subsequently structured as follows: Sect. 2 presents a review of relevant literature, followed by Sect. 3 with an explanation of the methodology employed. Sections 4 and 5 present data analysis with discussions of the results and conclusions respectively.

\section{Related Literature}

\subsection{Indigenous Innovation in Africa}

The growth of most economies in Africa is still slow, and only a handful of countries in the region have achieved inclusive growth. The Africa Economic Outlook Report (2020) states that if this trend continues the continent will not be able to eradicate extreme poverty by 2030 . The development of a science and technology strategy for Africa by the AU is a recognition of the fact that indigenous innovation is a catalyst for economic development. The Africa Innovation Outlook III (2019) reveals the rate of innovation by firms of some African countries ranges from as low as $3.9 \%$ for Cabo Verde to as high as $91.7 \%$ for Uganda. The average percentage of innovative firms according to data from ten countries shows an average of $58.6 \%$ of firms churning innovations. The report further states the main constraints to innovation in the continent include lack of qualified personnel, inadequate funds, limited external funding, and dominance by established firms. Some studies have attributed the slow growth of innovation in Africa to several factors including the level of human capital, economic infrastructure and lack of an enabling environment to propel innovation (Atiase, Mahmood, Wang, \& Botchie, 2018; Barasa, Knoben, Vermeulen, Kimuyu, \& Kinyanjui, 2017; Story, Boso, \& Cadogan, 2015). This indicates that firms in the region can stand out and be innovative even in the face of the challenges listed above. Indeed, the Global Innovation Index report (2019) states that since 2012, more economies in Sub-Saharan Africa have made it into the group of innovation achievers than those in other regions.

The Africa Union has conceived an ambitious objective to become the next home of manufacturing in the world in a quest to fulfill Agenda 2063 (Africa Innovation Outlook Report, 2019). The report further states that more firms in the region introduced more product and process innovations than organizational and marketing innovations within the reporting period. Table 1 reports the rate and types of innovations reported by ten African countries.

Table 1

Innovation among Firms in Selected African Countries

\begin{tabular}{|c|c|c|c|c|c|c|c|c|c|c|}
\hline \multirow[b]{2}{*}{ Country } & \multirow[b]{2}{*}{$\begin{array}{l}\text { All } \\
\text { firms }\end{array}$} & \multirow{2}{*}{$\begin{array}{l}\begin{array}{l}\text { Product } \\
\text { innovation }\end{array} \\
\text { New } \\
\text { goods/services }\end{array}$} & \multirow{2}{*}{$\begin{array}{l}\text { Process } \\
\text { innovation }\end{array}$} & \multicolumn{3}{|c|}{ Organizational innovation } & \multicolumn{4}{|c|}{ Marketing innovation } \\
\hline & & & & $\begin{array}{l}\text { New } \\
\text { Business } \\
\text { practices }\end{array}$ & $\begin{array}{l}\text { New work } \\
\text { responsibilities }\end{array}$ & $\begin{array}{l}\text { External } \\
\text { relations }\end{array}$ & $\begin{array}{l}\text { Significant } \\
\text { changes } \\
\text { to designs }\end{array}$ & $\begin{array}{l}\mathrm{New} \\
\text { media or } \\
\text { techniques }\end{array}$ & $\begin{array}{l}\text { New } \\
\text { methods for } \\
\text { product } \\
\text { placement }\end{array}$ & $\begin{array}{l}\text { New } \\
\text { methods } \\
\text { of pricing } \\
\text { goods }\end{array}$ \\
\hline Angola & 41 & 31 & 25 & 17 & 21 & 13 & 13 & 16 & 16 & 16 \\
\hline $\begin{array}{l}\text { Carbo } \\
\text { Verde }\end{array}$ & 3067 & - & 67 & 35 & 39 & 17 & 32 & - & 41 & 58 \\
\hline Egypt & 2985 & 764 & 1027 & - & - & - & - & - & - & - \\
\hline Eswatini & 149 & 53 & 55 & 45 & 65 & 34 & 44 & 46 & 36 & 36 \\
\hline Ethiopia & 10740 & 2541 & 3208 & 2466 & 2975 & 1963 & 3511 & 2890 & 1011 & 2698 \\
\hline Kenya & 376 & 302 & 209 & 161 & 239 & 143 & 156 & 178 & 0 & 0 \\
\hline Lesotho & 36 & 16 & 11 & 16 & 12 & 20 & 15 & 10 & 11 & 14 \\
\hline Namibia & 68 & 40 & 31 & 0 & 30 & 21 & 22 & 16 & 16 & 16 \\
\hline Seychelles & 15 & 14 & 10 & 7 & 8 & 5 & 6 & 6 & 5 & - \\
\hline Uganda & 6033 & 5896 & 3948 & 3417 & 4112 & 2835 & 2370 & 2635 & 2502 & 3261 \\
\hline
\end{tabular}

From Table 1, we deduce that product innovation in the form of new goods and services and process innovation fairly dominate other forms of innovation among firms in the region. A closer look at both forms of innovation shows that process innovation is more prominent among firms than product innovation. Organizational innovation among firms is geared toward improving workplace responsibilities and improved business practices. These forms of organizational innovation encourage staff of the organization to be creative and come up with new ideas that will ultimately result in product and process innovations. Marketing innovation has been focused more on new media promotional techniques. This could be linked directly to the presence of various internet applicaitons that people are continually exposed to. The World Internet Statistics report (2019) puts Africa's Internet penetration at 39.3\% as at the end of December 2019. This is an enormous increase in Internet penetration in the region over the last ten years. A lot more people in the region are using social media and other forms of new media that make it easier for businesses to bypass traditional media and reach their target customers more efficiently.

\subsection{The main drivers of Innovation}

The drivers of innovation in developing economies remains unclear despite the existence of several scholarly works on this subject (Fernández-Mesa, AlegreVidal, Chiva-Gómez, \& Gutiérrez-Gracia, 2013). In the African context there is very little literature on this issue (Victor Yawo Atiase et al., 2018) The Africa 
Innovation Outlook (2019) indicates that the main sources of knowledge for innovation in the region (shown in Table 2) come from suppliers, customers, and consultants. Relatively fewer numbers of firms make use of knowledge from universities and research institutions.

Table 2

Drivers of Indigenous Innovation in Africa

\begin{tabular}{|c|c|c|c|c|c|c|c|c|c|c|c|}
\hline \multicolumn{12}{|c|}{ Sources of Information for Innovation } \\
\hline \multirow[t]{4}{*}{ Country } & \multirow{4}{*}{$\begin{array}{l}\text { Total } \\
\text { number } \\
\text { of } \\
\text { firms }\end{array}$} & \multirow{3}{*}{$\begin{array}{l}\text { Internal } \\
\text { Source }\end{array}$} & \multicolumn{9}{|c|}{ External Sources } \\
\hline & & & \multicolumn{3}{|c|}{ External Sources (Market) } & \multirow[b]{2}{*}{ Consultants } & \multicolumn{3}{|c|}{ External Sources (Institutional) } & \multicolumn{2}{|c|}{ External Sources ( } \\
\hline & & & $\begin{array}{l}\text { Suppliers } \\
\text { of } \\
\text { equipment }\end{array}$ & Clients & Competitors & & Universities & Government & Conferences & $\begin{array}{l}\mathrm{SCl} \\
\text { Journals }\end{array}$ & $\begin{array}{l}\text { Profes } \\
\text { Assoc }\end{array}$ \\
\hline & & $\%$ & $\%$ & $\%$ & $\%$ & $\%$ & $\%$ & $\%$ & $\%$ & $\%$ & $\%$ \\
\hline Angola & 41 & 41.5 & 29.3 & 26.8 & 9.8 & 7.3 & 2.4 & 9.8 & 14.6 & 7.3 & 4.9 \\
\hline $\begin{array}{l}\text { Cabo } \\
\text { Verde }\end{array}$ & 3067 & 0.5 & 0.4 & 0.3 & 0.2 & 0.0 & 0.0 & 0.0 & 0.1 & 0.1 & 0.0 \\
\hline Egypt & 2985 & 24.7 & 13.8 & 10.9 & 6.7 & 2.0 & 0.9 & 0.8 & 5.3 & 3.8 & 1.3 \\
\hline Eswatini & 149 & 34.2 & 24.2 & 24.2 & 18.1 & 16.8 & 8.7 & 11.4 & 8.1 & 4.7 & 10.1 \\
\hline Ethiopia & 10740 & 28.3 & 12.4 & 23.0 & 10.5 & 2.1 & 1.8 & 2.5 & 7.8 & 3.1 & 1.8 \\
\hline Kenya & 376 & 44.9 & 28.7 & 35.6 & 20.5 & 12.0 & 9.6 & 12.8 & 19.4 & 10.9 & 15.4 \\
\hline Lesotho & 36 & 63.9 & 55.6 & 69.4 & 52.8 & 36.1 & 33.3 & 44.4 & 50.0 & 52.8 & 50.0 \\
\hline Namibia & 68 & 30.9 & 25.0 & 17.6 & 11.8 & 13.2 & 4.4 & 1.5 & 7.4 & 5.9 & 8.8 \\
\hline Seychelles & 15 & 33.3 & 40.0 & 53.3 & 13.3 & 20.0 & 0.0 & 6.7 & 26.7 & 20.0 & 20.0 \\
\hline Uganda & 6475 & 45.1 & 22.4 & 19.2 & 23.0 & 11.7 & 8.0 & 7.7 & 13.1 & 9.4 & 11.3 \\
\hline
\end{tabular}

Source: Africa Innovation Outlook III (AU-NEPAD, 2019)

Egbetokun et al. (2016) argue that innovation involves the connectivity of several actors in which producers of products depend on their external partners such as suppliers, customers, and competitors for information on new product development. Atiase \& Dzansi (2020) found that human capital, collaborative networks, and competitiveness all have a significant effect on innovation among firms in the African continent. Studying the Ghanaian situation, (Abdulai, Murphy, \& Thomas, 2020) found that University-industry collaboration promotes innovation among firms, while the informal transfer of knowledge from Universities had no significant effect. Other scholars have found that collaborative research, research and development (R\&D), required technology inputs and customer ideas are important factors that drive innovation (Fernández-Mesa et al., 2013; Valencia et al., 2010). Chatterji \& Fabrizio (2014) further affirmed that input by users of products contributes about $80 \%$ of the sources of knowledge for innovation across different industries. One thing that stands out from the above is the importance of stakeholders such as customers, suppliers, and competitors as sources of knowledge for innovation. This assertion holds for countries in Africa as evidenced by the African Innovation Outlook report (2019).

\subsection{The Role of Trade Openness in Indigenous Innovation}

The relationship between trade openness and innovation has spurred several studies in both the developed and developing worlds. Das \& Drine (2020) showed that globalization goes beyond the mere opening of new markets. It is aimed at achieving productivity through technology transfers. Trade openness encourages the import of technological products that can serve as inputs to innovation. Imported inputs are among the critical factors contributing to firm productivity in domestic markets (Gopinath \& Neiman, 2014; Foster-McGregor et al., 2014; Okafor et al., 2017). However, the existence of technology gaps between countries makes it imperative for policymakers to develop and implement appropriate national innovation systems as part of overall development objectives (Aguirre-Bastos \& Weber, 2018). Studies have shown that the aftermath of trade liberalization has witnessed increased innovation efforts as a result of foreign goods flooding local markets (lacovone, Keller and Rauch, 2011; lacovone, 2012; Fernandes and Paunov, 2013). Fernandes \& Paunov (2013) argued that competition from imported products has enhanced innovation more in large and technologically advanced firms than in small enterprises that constitute a large chunk of businesses in developing economies (lacovone, 2012). Import competition can lead to product upgrading opportunities (Medina 2017), and local firms will react to changing preferences of consumers by producing new products (Bloom et al., 2016). Other reasons given by many authors for the positive effect of imports on innovation is the idea of access to intermediate goods that serve as inputs to new product designs. These inputs have become common due to the presence of foreign firms in the local markets, hence giving local businesses easy access to new technologies (Bøler, Moxnes and UlltveitMoe, 2015; Fieler, Eslava and Xu, 2018).

Moreover, foreign direct investment inflows (FDI) is one major economic activity that is associated with trade openness (Kumari \& Sharma, 2017). Most developing counties benefit from novel technologies that come with foreign investors. Kastrati et al. (2016) among others have argued that technologies that come into the local market as a result of FDI activities have a positive effect on local innovation. Cheung and Ping (2004) opined that FDI comes with three main benefits to the receiving country. First, businesses of the receiving country adopt ideas from foreign counterparts and feed into their innovation efforts. Second, there is a spillover of knowledge as a result of people working with foreign firms and later working for domestic firms. Third, foreign technologies in 
the domestic markets spur local firms to be more creative in bringing out new products. The integration of new knowledge learned from foreign firms with local knowledge can lead to successful indigenous innovation (Cassiman \& Veugelers, 2002). Howell (2019) also points out that local firms benefit from FDI to complement R\&D spending, and recombine knowledge from related industries. For Tang \& Hussler (2011), Chinese innovation operates on two main systems that are interlinked: indigenous innovation and FDI-based systems. Based on the above assertions, it is evident that developing countries stand the chance of benefiting from new technologies and the requisite expertise from foreign investors to facilitate the process of indigenous innovation.

The Global Innovation Index (GII) report (2019) states that Hong Kong, Singapore, and Luxembourg have had high performance in innovation due to some enabling factors including trade openness. The practice of opening up their economies to international trade have made these states the hubs of trade and investment in their respective regions. Learning-y-by-doing has become an important element in absorbing spillovers from foreign firms operating in the domestic market. The absorption of spillovers has a positive and significant effect on innovation output and performance, especially with firms that have the requisite expertise to absorb and use new technologies (Baark, 2019).

The above literature shows a rich account of the main drivers of innovation in developing economies. It further demonstrates the interest of many scholars in the subject of trade openness and its effect on innovation. The position of the present study is to highlight how trade openness has contributed to indigenous innovation in the Africa region. An in-depth analysis of this phenomenon is done for each of the countries involved in the study.

\section{Materials And Methods}

To achieve the objective of this study, we employ a vector error correction model (VECM) to test for short-run causal relationships among the variables, and generalized least squares to further assess the long-run relationships that exist between them. To analyze this model effectively, we first test for stationarity of the variables. A further test for cointegration among the variables is done to establish the existence of long-run cointegration among the variables. The existence of long-run cointegration will make it appropriate to run the VECM to confirm the existence of causality among the variables.

\subsection{Data}

Data for this study is taken from the World Development Indicators (WDI) by the World Bank Group (www.data.worldbank.org/indicator). The data covers five countries across the continent of Africa including Egypt, Morocco, Algeria, Tunisia, and South Africa. These countries were selected based on prominence in innovation within the continent (Global Innovation Index, 2019) and data availability. South Africa, Egypt, Morocco, and Tunisia are among the nine African countries that made to the top 100 countries in the innovation index, while Algeria is ranked 113th. Data on trademark registrations in the Africa region is still scant, and these selected countries are those that have data on this variable on the WDI.

\subsection{Variables for the study}

The main variables for this study are trademark applications by residents, investments in R\&D, imports, and FDI. The dependent variable is trademark applications, while the rest are independent variables. The mean distribution of these variables is represented in Fig. 1. The average number of trademark applications for the period is above that of Algeria, South Africa, and Tunisia. It is almost at the same level as that of Morocco and a little below that of Egypt. The dependent variable being tested in this study is indigenous innovation at the country level. Trademark application is used in this case as a proxy for innovation, and since the focus is on indigenous innovation, we use trademark applications by residents of each country. Trademark applications are increasingly being used as proxy for product and service innovations in extant literature (Block, De Vries, Schumann, \& Sandner, 2014; Schautschick \& Greenhalgh, 2016; Gotsch \& Hipp, 2012; Yoshioka-Kobayashi, Miyanoshita, \& Kanama, 2020). A major advantage of the use of trademark applications as a proxy for innovation is the availability of data for most firms and countries (Crass, Czarnitzki, \& Toole, 2019; Flikkema, Castaldi, de Man, \& Seip, 2019).

Three main economic activities that come with trade openness are imports, foreign direct investments (FDI), and exports. This study assesses the causal effect of imports and FDI on indigenous innovation. Considering that the export of goods and services is an outward activity, we do not include it in this study. To understand how trade openness affects indigenous innovation in the Africa region, the study include research and development (R\&D) as an independent variable. R\&D is an important factor in the innovation process, therefore, while we assess the effect of imports and FDI on innovation output in the region, we find it necessary to also analyze how these variables affect R\&D investments, and how R\&D also impacts on indigenous innovation in the region.

\subsection{Empirical Model}

The main motive of this study is to analyze the effect of imports, FDI, and R\&D investments on indigenous innovation (trademark applications by residents) in Africa. Hence, we estimate the long-run relationship between the variables based on the following equation: 


$$
T M_{i t}=\alpha+\beta_{1} R \& D_{i t}+\beta_{2} I M P_{i t}+\beta_{3} F D I_{i t}+\theta_{i}+\epsilon_{i t}
$$

Where $i(i=1,2, \ldots, N$ represents the cross-sections, $t(t=1.2, \ldots, T)$ represents the time period. TM is the log of trademark applications, R\&D is the log of research and development expenditure, IMP is the log of imports, and FDI is the log of foreign direct investment inflows. $\theta$ denotes the individual country fixed effects, while $\varepsilon$ is the error term.

Based on proven procedures, we analyze this phenomenon in three stages. In the first stage, we test for stationarity of the series to determine their order of integration. If the series are found to be integrated, a panel cointegration will be used to establish a possible long-run relationship among the variables. In the final stage, we conduct a causality test using a panel vector error correction model (VECM) causality approach based on Engle and Granger (1987). Such estimations based on panel techniques are more advantageous over individual time series because the cross-sectional effect allows for more degrees of freedom and efficient model estimation (Seo, Kim, \& Kim, 2019). The long-run cointegration between variables is essential because it ensures the existence of an error correction mechanism which determines the speed of adjustment to equilibrium following any changes in the variables. Hence, Equation (1) can be written as a VECM model as follows:

$$
\begin{aligned}
\Delta T M_{i t}=\alpha_{1 i} & +\sum_{j=1}^{q} \beta_{11 i j} \Delta T M_{i t-j}+\sum_{j=1}^{q} \beta_{12 i j} \Delta R \& D_{i t-j}+\sum_{j=1}^{q} \beta_{13 i j} \Delta I M P_{i t-j} \\
& +\sum_{j=1}^{q} \beta_{14 i j} \Delta F D I_{i t-j}+\lambda_{i} E C T_{i t-1}+u_{1 i t} \\
\Delta R \& D_{i t}=\alpha_{2 i} & +\sum_{j=1}^{q} \beta_{21 i j} \Delta T M_{i t-j}+\sum_{j=1}^{q} \beta_{22 i j} \Delta R \& D_{i t-j}+\sum_{j=1}^{q} \beta_{23 i j} \Delta I M P_{i t-j} \\
& +\sum_{j=1}^{q} \beta_{24 i j} \Delta F D I_{i t-j}+\lambda_{i} E C T_{i t-1}+u_{2 i t} \\
\Delta I M P_{i t}=\alpha_{3 i} & +\sum_{j=1}^{q} \beta_{31 i j} \Delta T M_{i t-j}+\sum_{j=1}^{q} \beta_{32 i j} \Delta R \& D_{i t-j}+\sum_{j=1}^{q} \beta_{33 i j} \Delta I M P_{i t-j} \\
& +\sum_{j=1}^{q} \beta_{34 i j} \Delta F D I_{i t-j}+\lambda_{i} E C T_{i t-1}+u_{3 i t} \\
& +\sum_{j=1}^{q} \beta_{44 i j} \Delta F D I_{i t-j}+\lambda_{i} E C T_{i t-1}+u_{4 i t} \\
\Delta F D I_{i t}=\alpha_{4 i}+ & \sum_{j=1}^{q} \beta_{41 i j} \Delta T M_{i t-j}+\sum_{j=1}^{q} \beta_{42 i j} \Delta R \& D_{i t-j}+\sum_{j=1}^{q} \beta_{43 i j} \Delta I M P_{i t-j} \\
& (2 c)
\end{aligned}
$$

where $\Delta$ stands for the first-difference of the variable, $q$ denotes the lag length selected based on VAR lag length selection criteria, and $u$ is the error term. For equations $2 \mathrm{a}$ to $2 \mathrm{~d}$, the shortrun effects will be determined by the significance of the Wald $\mathrm{Chi}^{2}$ test statistics. The long-run dynamics are estimated using generalized least squares techniques.

\section{Results And Discussions}




\subsection{Unit root and cointegration tests}

The test for stationarity is conducted using the Fisher-ADF and Fisher-PP non-parametric tests which allow for heterogeneity across units. The LLC unit root test proposed by Levin et al. is also employed to test for unit root. This test assumes homogeneity in the autoregressive coefficients with cross-sectional independence. The hypotheses for these tests are $\mathrm{H}_{0}$ : series are not stationary, and $\mathrm{H}_{1}$ : series are stationary. The results of these tests in Table 3 show that all series are stationary at first difference $(/(1))$. This result allows for the test for cointegration to establish the existence of a long-run relationship among the variables. The VECM can be applied if a cointegration relationship is found between the variables. Therefore, we test for this cointegration using the Johansen cointegration test following the stationarity of the variables at first difference. The results of the Johansen test (in Table 4) show the variables are cointegrated for the full sample and individual countries for both trace and maximum Eigenvalue statistics. Hence, we conclude that there exists a long-term stable relationship between the variables under study.

Table 3

Test of stationarity

\begin{tabular}{|c|c|c|c|c|c|c|c|c|c|}
\hline & At leve & & & & At first di & ference & & & Stationarity \\
\hline Test & TM & $R \& D$ & IMP & FDI & TM & $R \& D$ & IMP & FDI & $/(1)$ \\
\hline ADF & 11.45 & 7.28 & 7.69 & 8.63 & $48.36^{a}$ & $26.40^{a}$ & $24.72^{\mathrm{a}}$ & $47.12^{p}$ & $/(1)$ \\
\hline PP & 18.14 & 16.14 & 5.30 & 39.35 & $347.01^{p}$ & $81.57^{p}$ & $41.67^{p}$ & $808.44^{\mathrm{p}}$ & $/(1)$ \\
\hline LLC & -1.24 & 2.45 & 1.30 & 1.48 & $-5.77^{p}$ & $1.24^{\mathrm{p}}$ & $-3.98^{p}$ & $-0.63^{p}$ & $/(1)$ \\
\hline
\end{tabular}

Table 4

Results of Johansen Cointegration Rank Test

\begin{tabular}{|c|c|c|c|c|}
\hline \multirow[t]{2}{*}{ Cointegration equations } & \multicolumn{2}{|l|}{ Trace test } & \multicolumn{2}{|c|}{ Maximum eigenvalue test } \\
\hline & Trace stat & $5 \%$ critical value & Max. eigenvalue stat & $5 \%$ critical value \\
\hline \multicolumn{5}{|l|}{ Full sample } \\
\hline$r=0 *$ & 54.08325 & 47.85613 & 36.03575 & 27.58434 \\
\hline$r \leq 1$ & 18.04749 & 29.79707 & 11.97781 & 21.13162 \\
\hline \multicolumn{5}{|l|}{ Algeria } \\
\hline$r=0 *$ & 64.76906 & 47.85613 & 42.27557 & 27.58434 \\
\hline$r \leq 1$ & 22.49349 & 29.79707 & 12.71784 & 21.13162 \\
\hline \multicolumn{5}{|l|}{ Egypt } \\
\hline$r=0 *$ & 99.55970 & 47.85613 & 56.26584 & 27.58434 \\
\hline$r \leq 1$ & 43.29386 & 29.79707 & 38.28011 & 21.13162 \\
\hline \multicolumn{5}{|l|}{ Morocco } \\
\hline$r=0 *$ & 79.25507 & 47.85613 & 42.50066 & 27.58434 \\
\hline$r \leq 1^{*}$ & 36.75442 & 29.79707 & 21.61926 & 21.13162 \\
\hline \multicolumn{5}{|l|}{ South Africa } \\
\hline$r=0 *$ & 96.90903 & 47.85613 & 47.17377 & 27.58434 \\
\hline$r \leq 1^{*}$ & 49.73526 & 29.79707 & 34.78146 & 21.13162 \\
\hline \multicolumn{5}{|l|}{ Tunisia } \\
\hline$r=0 *$ & 72.97486 & 47.85613 & 37.29074 & 27.58434 \\
\hline$r \leq 1^{*}$ & 35.68412 & 29.79707 & 23.20309 & 21.13162 \\
\hline
\end{tabular}

\subsection{Model Estimation}

We test for the short-run causalities using the Wald $\mathrm{Chi}^{2}$ test of the VECM. First, the short-run dynamics are estimated for the full panel involving the five countries, then the estimates for individual countries are done. Second, we estimate the long-run elasticities between the independent variables and the dependent variable using fully modified ordinary least squares (FMOLS) and Generalized Least Squares (GLS). The GLS will serve as a robustness check on the FMOLS to ensure the results are reliable. The specific method of GLS employed is Fixed Effects. To decide between Fixed Effects (FE) and Random Effects 
(RE), we conducted a Hausman test. The $\mathrm{Chi}^{2}$ statistic of the Hausman test is 103.02 with a $p$-value $<1 \%$ significance level. Hence, the null hypothesis of RE being a better estimator was rejected in favor of FE. The appropriate lag length is set at 2 following the Schwarz and Hannan-Quinn information criteria.

Model diagnostics were conducted using the Lagrange multiplier (LM) test for serial correlation, heteroscedasticity test (HE), and Regression Equation Specification Error Test (RESET). The results of these tests show $L M=1.11(0.34), \mathrm{HE}=1.32(0.38)$ and RESET $=1.45(0.29)$ denoting an acceptance of the null hypotheses of no serial correlation, homoscedasticity and no specification error respectively. The estimation of both the short-run and long-run dynamics resulted in the findings discussed below.

Table 5 shows the results of the causal relationship between the variables for the short-run based on the Wald Chi ${ }^{2}$ stats. For the full sample, short-run causalities are observed between all the independent variables and innovation output. Thus both imports and FDI have shot-run causal relationships with indigenous innovation efforts. Domestic R\&D investments also show up as a useful activity in promoting indigenous innovation among developing economies. These short-run causalities are mainly influenced by Egypt and Tunisia where such causalities are observed for both imports and FDI. This shows that imported inputs and spill-overs from FDI investments in the domestic markets do have an impact on indigenous innovation in the continent. Furthermore, it is evident that imports and FDI spill-overs have a short-run causal relationship with domestic investments in R\&D. R\&D ultimately leads to innovation activities, hence, this relationship between imports, FDI, and R\&D is an important factor in determining how these activities associated with trade openness impact on indigenous innovation in the continent.

However, some countries show short-run causal relationship between innovation and one independent variable or the other. The evidence suggests that for Algeria imports have no short-run causal effect on innovation output, while a short-run causal relationship exists between only FDI and innovation output in South Africa. For Morocco, no short-run causal relationship exists between import, FDI, and innovation output. Interestingly, besides Egypt and South Africa, there is no short-run causal relationship between $R \& D$ and innovation for the others.

Following the above findings, we test for the long-run dynamics between the independent and dependent variables based on Eq. (1). These long-run dynamics will show the strength and direction of the relationship between variables. The results of the FMOLS in Table 6 show significant relationships between the independent and the dependent variables. First, we find that for the full sample, domestic investments in R\&D have a significant and positive effect on indigenous innovation. A percentage increase in the amount invested in R\&D leads to a $0.22 \%$ increase in the number of trademarks registered by residents in the countries under study. In line with this, imported inputs also have a significant and positive effect on indigenous innovation. Resources and technologies from other countries push up the number of indigenous trademarks by $1.14 \%$ per percentage increase in such imports. However, FDI inflows have a negative and significant effect on indigenous innovation. Increases in FDI inflows by every percentage leads to a $0.074 \%$ decrease in indigenous innovation output.

Moreover, the findings are fairly the same for some of the individual countries tested. Apart from Algeria and Morocco where no significant effects are observed, investments in R\&D have a positive and significant effect on indigenous innovation for the rest of the countries under study. Tunisia is the biggest beneficiary of these investments as indigenous innovation output is increased by $1.47 \%$ per percentage increase in R\&D expenditure. Imports generally have positive and significant effects on innovation output for all countries studied. Once again, Tunisia shows up as the biggest beneficiary of such imports, and South Africa shows the least amount of effect on indigenous innovation by imported inputs. In contrast, FDI inflows have shown a negative and significant effect on innovation output for Egypt, South Africa, and Tunisia. For Algeria and Morocco, no significant effect is observed. The evidence, on the whole, shows that indigenous innovation in Africa is suppressed by FDI inflows. The impact of imports, however, shows up as a significant contributor to indigenous innovation efforts in the continent.

These findings are in line with research findings in other developing countries (Bashir, Khan, \& Malik, 2010; Baumann \& Kritikos, 2016; Anzola-Román, BayonaSáez, \& García-Marco, 2018) which demonstrated a positive and significant effect of R\&D on innovation output. The import of technologies from other countries serve as useful inputs to the innovation process in the African continent as has been found in other countries (Wang \& Wong, 2012; Xie and Li, 2018; Shu and Steinwender, 2019). The result also confirms the evidence in the Africa Innovation Outlook report (2019) which finds that suppliers are major contributors to innovation in the continent. Suppliers from external markets are found in this study to have an important influence on the indigenous innovation process on the continent. Similarly, the negative effect of FDI inflows on indigenous innovation has been established in the literature (Aitken \& Harrison, 1999; Hu \& Jefferson, 2002; Zanello, Fu, Mohnen, \& Ventresca, 2016). 
Table 5. Results of VECM short-run causalities

\begin{tabular}{|c|c|c|c|c|c|}
\hline \multirow[t]{2}{*}{$\begin{array}{c}\text { Dependent } \\
\text { variables }\end{array}$} & \multicolumn{4}{|c|}{ Independent variables } & \multirow{3}{*}{$E C T$} \\
\hline & \multicolumn{4}{|c|}{ Short-run effects (Wald Chi ${ }^{2}$ ) } & \\
\hline Full sample & $\Delta T M_{i t}$ & $\Delta R D_{\text {it }}$ & $\Delta I M P_{i t}$ & $\triangle F D I_{\text {it }}$ & \\
\hline$\Delta T M_{i t}$ & - & 2.54 & 2.07 & 1.50 & -0.001 \\
\hline$\Delta R D_{i t}$ & $14.44^{* *}$ & - & 2.52 & $8.02^{* *}$ & $-0.010^{* *}$ \\
\hline$\Delta I M P_{i t}$ & $13.53^{* *}$ & $23.08^{* * *}$ & - & $11.37^{* *}$ & $-0.030 * *$ \\
\hline$\Delta F D I_{\text {it }}$ & $13.86^{* *}$ & $22.69^{* * *}$ & 1.04 & - & $-0.070^{* *}$ \\
\hline
\end{tabular}

\begin{tabular}{|c|c|c|c|c|c|}
\hline Algeria & & & & & \\
\hline$\Delta T M_{i t}$ & - & 3.50 & 1.84 & 2.19 & $-0.109^{*}$ \\
\hline$\Delta R D_{i t}$ & 2.70 & - & 1.85 & 3.12 & -0.823 \\
\hline$\Delta I M P_{i t}$ & $14.09^{* *}$ & 3.56 & - & 1.45 & $0.028^{* *}$ \\
\hline$\Delta F D I_{i t}$ & 1.22 & 2.30 & 2.77 & - & $0.837^{* *}$ \\
\hline
\end{tabular}

Egypt
\begin{tabular}{c|c|c|c|c|c}
\hline $\boldsymbol{T} \boldsymbol{M}_{\text {it }}$ & - & 3.65 & 2.35 & 1.22 & $-0.885^{* *}$ \\
\hline$\Delta \boldsymbol{R} \boldsymbol{D}_{\text {it }}$ & $18.03^{* *}$ & - & 0.44 & 3.08 & $-0.138^{*}$ \\
\hline$\Delta \boldsymbol{I M P _ { i t }}$ & $13.32^{* *}$ & $5.96^{* *}$ & - & 1.11 & 0.157 \\
\hline$\Delta \boldsymbol{F} \boldsymbol{D} \boldsymbol{I}_{\text {it }}$ & $16.78^{* *}$ & 3.65 & 1.73 & - & $-1.866^{*}$ \\
\hline
\end{tabular}

\begin{tabular}{|c|c|c|c|c|c|}
\hline Morocco & & & & & \\
\hline$\Delta T M_{i t}$ & - & 0.08 & 2.35 & $7.75^{\circ \bullet}$ & $-0.418^{* *}$ \\
\hline$\Delta R D_{i t}$ & 0.36 & - & 1.26 & $6.30^{* * *}$ & -0.195 \\
\hline$\Delta I M P_{i t}$ & 1.42 & 0.74 & - & 3.71 & 0.051 \\
\hline$\Delta F D I_{i t}$ & 4.21 & $15.39^{* *}$ & 0.13 & - & $-1.410^{* *}$ \\
\hline
\end{tabular}

\begin{tabular}{|c|c|c|c|c|c|}
\hline \multicolumn{6}{|l|}{ Tunisia } \\
\hline$\Delta T M_{i t}$ & - & 2.53 & 0.30 & 0.27 & $-1.34^{* *}$ \\
\hline$\Delta R D_{i t}$ & $13.96^{* *}$ & - & 0.11 & 0.07 & $-0.105^{* *}$ \\
\hline$\Delta I M P_{i t}$ & $12.67^{* *}$ & 1.32 & - & $6.88^{*}$ & -0.004 \\
\hline$\Delta F D I_{i t}$ & $12.19^{* *}$ & 1.34 & $6.87^{*}$ & - & -0.002 \\
\hline
\end{tabular}

\begin{tabular}{|c|c|c|c|c|c|}
\hline \multicolumn{6}{|l|}{ South Africa } \\
\hline$\Delta T M_{i t}$ & - & 3.68 & 1.13 & 3.52 & $-0.389 * *$ \\
\hline$\Delta R D_{i t}$ & $16.60^{* *}$ & - & 1.17 & 4.05 & 0.018 \\
\hline$\Delta I M P_{i t}$ & 2.30 & 2.38 & - & 2.31 & $-0.291^{8}$ \\
\hline$\Delta F D I_{\text {it }}$ & $12.65^{* *}$ & 2.76 & $7.61^{*}$ & - & $-1.944 * *$ \\
\hline
\end{tabular}

Note: ${ }^{* * *},{ }^{* *}$, and ${ }^{*}$ denote significance levels of $0.01,0.05$ and 0.10 respectively.

Table 6

Results of Long-run Causalities

\begin{tabular}{|c|c|c|c|c|c|c|c|}
\hline & Full Sample & & Algeria & Egypt & Morocco & South Africa & Tunisia \\
\hline & Fixed Effects & \multicolumn{6}{|c|}{ Fully Modified Ordinary Least Squares } \\
\hline \multirow[t]{2}{*}{$\mathrm{R} \& \mathrm{D}$} & $0.172 * \star$ & $0.221 * \star$ & 0.052 & $0.119 *$ & 0.098 & $0.103^{\star \star}$ & $1.477 * \star \star$ \\
\hline & $(0.066)$ & $(0.084)$ & $(0.177)$ & $(0.094)$ & $(0.247)$ & $(0.046)$ & $(0.276)$ \\
\hline \multirow[t]{2}{*}{ Imports } & $1.079 * \star \star$ & 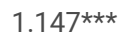 & $1.198 * \star \star$ & $0.838 * \star \star$ & $0.717 *$ & $0.683^{\star \star \star}$ & $3.817 * \star \star$ \\
\hline & $(0.086)$ & $(0.107)$ & $(0.162)$ & $(0.166)$ & $(0.360)$ & $(0.063)$ & $(0.640)$ \\
\hline \multirow[t]{2}{*}{ FDI } & $-0.066^{\star \star}$ & $-0.074 * \star$ & 0.003 & $-0.066^{\star}$ & -0.088 & $-0.235^{\star \star}$ & -0.142 \\
\hline & $(0.030)$ & $(0.037)$ & $(0.093)$ & $(0.037)$ & $(0.083)$ & $(0.115)$ & $(0.125)^{\star}$ \\
\hline \multirow[t]{2}{*}{ Constant } & $-5.693 * \star \star$ & - & $-9.808 * \star \star$ & $-4.305^{\star \star \star}$ & $-3.725^{\star \star}$ & $-6.397 * \star \star$ & -4.244 \\
\hline & $(0.470)$ & & $(1.169)$ & $(1.016)$ & $(2.002)$ & $(1.635)$ & $(1.415)$ \\
\hline Adj. $\mathrm{R}^{2}$ & 0.954 & 0.952 & 0.763 & 0.855 & 0.698 & 0.702 & 0.642 \\
\hline S.E. of Regression & 0.095 & 0.223 & 0.137 & 0.070 & 0.086 & 0.103 & 0.113 \\
\hline F-statistic & 374.742 & & & & & & \\
\hline Prob(F-stat) & 0.000 & & & & & & \\
\hline
\end{tabular}

\section{Conclusions}

The focus of this study is to analyze how imports and foreign direct investment inflows (FDI) contribute to the growth of indigenous innovation in the African continent. To analyze this effectively, we also added the element of domestic R\&D investments to gauge how imports and FDI impact R\&D as well, and how 
this R\&D also impacts on indigenous innovation. To address these issues the study adopted the vector error correction model (VECM) to study the short-run causalities between R\&D, imports, FDI, and indigenous innovation output (measured as trademarks registered by residents of the countries under study). To estimate the long-run dynamics the study adopted the fully modified ordinary least squares and the fixed effects estimation methods. The study used panel data of five African countries for the period 1994 to 2018 taken from the World Development Indicators (WDI) of the World Bank group. The analyses began with a test of stationarity of the variables where the variables were seen to be stationary at first difference. Following this, a test for long-run cointegration was conducted which established a long-run cointegration relationship between variables based on the Johansen test. Based on these findings the VECM was then applied to test for short-run causalities between the variables, and subsequently the long-run elasticities for this analysis. The analyses resulted in the following conclusions.

First, in the short-run, domestic R\&D investments have causal relationships with indigenous innovation output. Imports and FDI also have short-run causal relationships with $R \& D$ in the countries under study. These causal relationships are very important since R\&D has a positive effect on innovation output in the domestic markets in the long-run. The long-run dynamics also show that the effect of R\&D on innovation output is positive and significant, especially for Tunisia, while that of Morocco shows no significant effects. Second, Imported products have short-run causal effects on innovation output for all countries apart from Morocco and South Africa. However, in the long term, the effect of imports on innovation is positive and significant for all countries. African countries are benefiting from imported inputs in the innovation process to propel the translation of indigenous knowledge into novel product ideas. Third, foreign direct investments (FDI) have both short-run and long-run relationships with indigenous innovation output. This causal relationship in the long-run analysis is negative and significant. This means that FDI inflows tend to suppress indigenous innovation ideas among firms in the continent.

Following the conclusions in this study, we make the following recommendations. First, domestic investments in R\&D are very important in the indigenous innovation process. The governments of Algeria and Morocco need to pay more attention to and give more incentives to indigenous firms enhance their capacity to translate R\&D investments into innovation output. Second, policy formulation by African countries concerning international trade should encourage the import of new technologies that are direct inputs to the innovation process. Businesses in the continent should be given tax and other financial incentives that will encourage and support their R\&D efforts. This will enhance their capacity to process much of the raw materials abundant in the continent into finished goods for domestic consumption and exports. Third, there is an urgent need to build the capacity of indigenous businesses to absorb and utilize new technologies brought into the domestic market by foreign investors. This will help in neutralizing the negative impact of FDI on indigenous innovation efforts in the continent.

The findings of this study provide very useful insights into how the African continent can benefit from international trade in an era when countries are opening up domestic markets to international businesses. The study is however limited in scope due mainly to data availability, future studies can expand this scope to cover more countries in the continent enrich literature and policy ideas on this phenomenon.

\section{Declarations}

Data availability: the study employs secondary data from the World Bank group (world development indicators), https://data.worldbank.org/indicator

Competing interests: Authors have no conflicting interest in this study.

Funding: This work is supported by the Social Science Funding Project of Jiangsu Province (No.18GLB024), and the National Natural Science Foundation of China (No.71573109; No.71974082)

Author Contributions: Conceptualization, Asunka, B. A.; methodology, Asunka, B. A. and Ma, Z.; literature, Anaba, O. A. and Li, M.; formal analysis, Asunka, B. A., Anaba, O. A. and Amowine, N.; writing-original draft preparation, Asunka, B. A. and Amowine, N.; writing-review and editing, Ma, Z. and Li, M.; supervision, Li, M. and Ma, Z.; funding acquisition, Ma, Z.

\section{References}

Abdulai, A.-F., Murphy, L., \& Thomas, B. (2020). University knowledge transfer and innovation performance in firms: the Ghanaian experience. International Journal of Innovation Management, 24(03), 2050023.

Aguirre-Bastos, C., \& Weber, M. K. (2018). Foresight for shaping national innovation systems in developing economies. Technological Forecasting and Social Change, 128, 186-196.

Aitken, B. J., \& Harrison, A. E. (1999). Do domestic firms benefit from direct foreign investment? Evidence from Venezuela. American Economic Review, 89(3), 605-618.

Anzola-Román, P., Bayona-Sáez, C., \& García-Marco, T. (2018). Organizational innovation, internal R\&D and externally sourced innovation practices: Effects on technological innovation outcomes. Journal of Business Research, 91, 233-247.

Atiase, Victor Y, \& Dzansi, D. Y. (2020). Investigating the drivers of product innovation in emerging markets: The African perspective. Strategic Change, 29(1), 89-101.

Atiase, Victor Yawo, Mahmood, S., Wang, Y., \& Botchie, D. (2018). Developing entrepreneurship in Africa: investigating critical resource challenges. Journal of Small Business and Enterprise Development.

Baark, E. (2019). China's Indigenous Innovation Policies. East Asian Policy, 11(02), 5-12.

Page 10/13 
Barasa, L., Knoben, J., Vermeulen, P., Kimuyu, P., \& Kinyanjui, B. (2017). Institutions, resources and innovation in East Africa: A firm level approach. Research Policy, 46(1), 280-291. https://doi.org/10.1016/j.respol.2016.11.008

Bashir, T., Khan, K., \& Malik, K. (2010). The innovation landscape of Pakistan's North West Frontier Province. Science and Public Policy, 37(3), $181-191$.

Baumann, J., \& Kritikos, A. S. (2016). The link between R\&D, innovation and productivity: Are micro firms different? Research Policy, 45(6), $1263-1274$. https://doi.org/10.1016/j.respol.2016.03.008

Block, J. H., De Vries, G., Schumann, J. H., \& Sandner, P. (2014). Trademarks and venture capital valuation. Journal of Business Venturing, $29(4), 525-542$.

Bloom, N., Draca, M., \& Van Reenen, J. (2016). Trade induced technical change? The impact of chinese imports on innovation, IT and productivity. Review of Economic Studies, 83(1), 87-117. https://doi.org/10.1093/restud/rdv039

Bøler, E. A., Moxnes, A., \& Ulltveit-Moe, K. H. (2015). R\&D, international sourcing, and the joint impact on firm performance. American Economic Review, 105(12), 3704-3739.

Botchie, D., Sarpong, D., \& Bi, J. (2017). Technological inclusiveness: Northern versus Chinese induced technologies in the garment industry. Technological Forecasting and Social Change, 119, 310-322.

Carlisle, S., Kunc, M., Jones, E., \& Tiffin, S. (2013). Supporting innovation for tourism development through multi-stakeholder approaches: Experiences from Africa. Tourism Management, 35, 59-69.

Cassiman, B., \& Veugelers, R. (2002). Complementarity in the innovation strategy: internal R\&D, external technology acquisition and cooperation.

Chatterji, A. K., \& Fabrizio, K. R. (2014). Using users: When does external knowledge enhance corporate product innovation? Strategic Management Journal, 35(10), 1427-1445.

Cheung, K., \& Ping, L. (2004). Spillover effects of FDI on innovation in China: Evidence from the provincial data. China Economic Review, 15(1), $25-44$.

Corchuelo, B., \& Carvalho, L. (2020). Innovative Activity And Propensity To Innovate In Extremaduran Kibs Companies. International Journal of Innovation Management, 24(07), 2050062.

Costa, R. V, Fernández, C. F.-J., \& Dorrego, P. F. (2014). Critical elements for product innovation at Portuguese innovative SMEs: an intellectual capital perspective. Knowledge Management Research \& Practice, 12(3), 322-338.

Crass, D., Czarnitzki, D., \& Toole, A. A. (2019). The dynamic relationship between investments in brand equity and firm profitability: Evidence using trademark registrations. International Journal of the Economics of Business, 26(1), 157-176.

Das, G. G., \& Drine, I. (2020). Distance from the technology frontier: How could Africa catch-up via socio-institutional factors and human capital? Technological Forecasting and Social Change, 150, 119755.

Debrah, Y. A., Oseghale, R. O., \& Adams, K. (2018). Human Capital, Innovation and International Competitiveness in Sub-Saharan Africa. Africa's Competitiveness in the Global Economy, 219-248. https://doi.org/10.1007/978-3-319-67014-0_9

Egbetokun, A., Atta-Ankomah, R., Jegede, O., \& Lorenz, E. (2016a). Firm-level innovation in Africa: overcoming limits and constraints. Innovation and Development, 6(2), 161-174. https://doi.org/10.1080/2157930x.2016.1224619

Egbetokun, A., Atta-Ankomah, R., Jegede, O., \& Lorenz, E. (2016b). Firm-level innovation in Africa: Overcoming limits and constraints. Routledge.

Egbetokun, A., Siyanbola, W., \& Adeniyi, A. (2007). Indigenous innovation capability in Sub-Saharan Africa: a review of the Nigerian situation.

Engle, R. F., \& Granger, C. W. J. (1987). Co-integration and error correction: representation, estimation, and testing. Econometrica: Journal of the Econometric Society, 251-276.

Fernandes, A. M., \& Paunov, C. (2013). Does trade stimulate product quality upgrading? Canadian Journal of Economics/Revue Canadienne d'économique, 46(4), 1232-1264.

Fernández-Mesa, A., Alegre-Vidal, J., Chiva-Gómez, R., \& Gutiérrez-Gracia, A. (2013). Design management capability and product innovation in SMEs. Management Decision.

Fieler, A. C., Eslava, M., \& Xu, D. Y. (2018). Trade, quality upgrading, and input linkages: Theory and evidence from Colombia. American Economic Review, 108(1), 109-146. https://doi.org/10.1257/aer.20150796

Flikkema, M., Castaldi, C., de Man, A.-P., \& Seip, M. (2019). Trademarks' relatedness to product and service innovation: A branding strategy approach. Research Policy, 48(6), 1340-1353.

Foster-McGregor, N., Isaksson, A., \& Kaulich, F. (2014). Importing, exporting and performance in sub-Saharan African manufacturing firms. Review of World Economics, 150(2), 309-336. https://doi.org/10.1007/s10290-013-0177-y

Page $11 / 13$ 
Gopinath, G., \& Neiman, B. (2014). Trade adjustment and productivity in large crises. American Economic Review, 104(3), 793-831.

Gotsch, M., \& Hipp, C. (2012). Measurement of innovation activities in the knowledge-intensive services industry: a trademark approach. The Service Industries Journal, 32(13), 2167-2184.

Gupta, A. Das. (2013). Does Indigenous Knowledge have anything to deal with Sustainable Development. Cultural Anthropology, $57,64$.

Howell, A. (2019). Industry relatedness, FDI liberalization and the indigenous innovation process in China. Regional Studies, 1-15.

Hu, A. G. Z., \& Jefferson, G. H. (2002). FDI impact and spillover: evidence from China's electronic and textile industries. World Economy, 25(8), $1063-1076$.

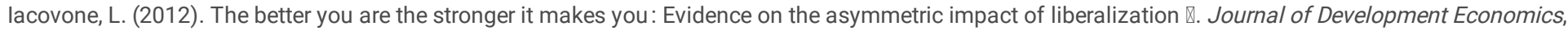
99(2), 474-485. https://doi.org/10.1016/j.jdeveco.2012.06.001

lacovone, L., Keller, W., \& Rauch, F. (2011). Innovation responses to import competition. mimeo, Princeton University, March.

lizuka, M., Mawoko, P., \& Gault, F. (2015). Innovation for development in Southern \& Eastern Africa: Challenges for promoting ST\&I policy. UNU-MERIT Policy Brief, 1, 1-8.

Intarakumnerd, P., \& Goto, A. (2018). Role of public research institutes in national innovation systems in industrialized countries: The cases of Fraunhofer, NIST, CSIRO, AIST, and ITRI. Research Policy, 47(7), 1309-1320.

Kastrati, S. K., Ramadani, V., Dana, L. P., \& Ratten, V. (2016). Do foreign direct investments accelerate economic growth? The case of the Republic of Macedonia. International Journal of Competitiveness, 1(1), 71. https://doi.org/10.1504/ijc.2016.075903

Kumari, R., \& Sharma, A. K. (2017). Determinants of foreign direct investment in developing countries: a panel data study. International Journal of Emerging Markets, 12(4), 658-682.

Liu, X., Schwaag Serger, S., Tagscherer, U., \& Chang, A. Y. (2017). Beyond catch-up-can a new innovation policy help China overcome the middle income trap? Science and Public Policy, 44(5), 656-669.

Medina, P. (2017). Import Competition, Quality Upgrading and Exporting: Evidence from the Peruvian Apparel Industry. University of Toronto Mimeo, 1-79.

Muok, B. O., \& Kingiri, A. (2015). The role of civil society organizations in low-carbon innovation in Kenya. Innovation and Development, 5(2), $207-223$.

Okafor, L. E., Bhattacharya, M., \& Bloch, H. (2017). Imported intermediates, absorptive capacity and productivity: evidence from Ghanaian manufacturing firms. The World Economy, 40(2), 369-392.

Poole, N., \& Penrose Buckley, C. (2006). Innovation challenges, constraints and opportunities for the rural poor.

Rodrigues, M. G., \& da Costa, F. J. P. (2018). Technology and Competitiveness: Technological Innovation for Developing Economies Growth. IJAME.

Schautschick, P., \& Greenhalgh, C. (2016). Empirical studies of trade marks-the existing economic literature. Economics of Innovation and New Technology, 25(4), 358-390.

Schumpeter, J. A. (1934). The Theory of Economic Development. Harvard University Press.

Seenaiah, K., \& Rath, B. N. (2018). Determinants of innovation in selected manufacturing firms in India: Role of R\&D and exports. Science, Technology and Society, 23(1), 65-84.

Seo, M. H., Kim, S., \& Kim, Y.-J. (2019). Estimation of dynamic panel threshold model using Stata. The Stata Journal, $19(3), 685-697$.

Shu, P., \& Steinwender, C. (2019). The impact of trade liberalization on firm productivity and innovation. Innovation Policy and the Economy, $19(1), 39-68$.

Story, V. M., Boso, N., \& Cadogan, J. W. (2015). The form of relationship between firm-level product innovativeness and new product performance in developed and emerging markets. Journal of Product Innovation Management, 32(1), 45-64.

Tang, M., \& Hussler, C. (2011). Betting on indigenous innovation or relying on FDI: The Chinese strategy for catching-up. Technology in Society, 33(1-2), 2335 .

Valencia, J. C. N., Valle, R. S., \& Jiménez, D. J. (2010). Organizational culture as determinant of product innovation. European Journal of Innovation Management.

Vinig, T., \& Bossink, B. (2015). China's indigenous innovation approach: the emergence of Chinese innovation theory? Technology Analysis \& Strategic Management, 27(6), 621-627.

Wang, M., \& Wong, M. C. S. (2012). International R\&D Transfer and Technical Efficiency: Evidence from Panel Study Using Stochastic Frontier Analysis. World Development, 40(10), 1982-1998. https://doi.org/10.1016/j.worlddev.2012.05.001 
Woetzel, J., Garemo, N., Mischke, J., Hjerpe, M., \& Palter, R. (2016). Bridging global infrastructure gaps. McKinsey Global Institute, $199-217$.

Xie, Z., \& Li, J. (2018). Exporting and innovating among emerging market firms: The moderating role of institutional development. Journal of International Business Studies, 49(2), 222-245.

Yepes, T., Pierce, J., \& Foster, V. (2009). Making sense of Africa's infrastructure endowment: a benchmarking approach. The World Bank.

Yoshioka-Kobayashi, T., Miyanoshita, T., \& Kanama, D. (2020). Revisiting incremental product innovations in the food-manufacturing industry: an empirical study on the effect of intellectual property rights. Journal of Economic Structures, 9, 1-19.

Zanello, G., Fu, X., Mohnen, P., \& Ventresca, M. (2016). the Creation and Diffusion of Innovation in Developing Countries: a Systematic Literature Review. Journal of Economic Surveys, 30(5), 884-912. https://doi.org/10.1111/joes.12126

\section{Figures}

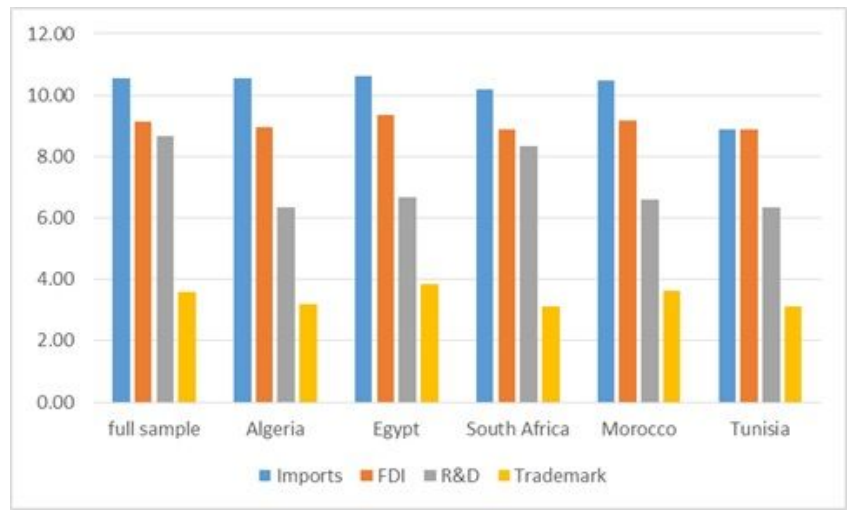

Figure 1

Mean Distribution of Variables 